\title{
A CAUSAL MODEL OF FACTORS INFLUENCING FACULTY USE OF TECHNOLOGY
}

\author{
Katrina A. Meyer \\ Higher and Adult Education \\ The University of Memphis \\ Yonghong Jade Xu \\ Counseling, Educational Psychology and Research \\ University of Memphis
}

\begin{abstract}
Based on earlier studies using the 1999 and 2004 National Study of Postsecondary Faculty (NSOPF) data $[1,2]$, a causal model explaining faculty technology use was constructed. Path analysis was used to test the causal effects of age, gender, highest degree, discipline (health science or not), recent research productivity, and teaching load on faculty use of websites in teaching. Two models, one for faculty from Research I institutions and the other for faculty from Community Colleges, were tested and both models fit the data with satisfying indices. Results confirmed that age, highest degree, and teaching loads influenced technology use directly, but indicated the lack of relationship between research productivity and technology use in teaching. An additional connection is suggested from discipline to teaching load. One important difference between the two models is that the impact of gender and teaching load on research productivity is significant for faculty at Research institutions, but not for faculty at community colleges. The models confirm the consistent and relatively strong relationship of teaching load to faculty technology use.
\end{abstract}

\section{KEY WORDS}

Faculty Technology Use, Research Universities, Community Colleges

\section{INTRODUCTION}

Why is there such interest in whether and to what extent faculty use technology in higher education? Certainly, the interest may simply be because students come to college with an interest in the latest technologies [3] or that employers insist that students graduate with appropriate technical skills [4]. But it is also possible that technology has become, in the minds of some state and higher education leaders, a "silver bullet" that can solve higher education's problems of low productivity or poor performance $[5,6]$. Clearly, higher education institutions are interested in seeing faculty use of technology increase as evidenced by a focus on faculty development, growth of distance education, and e-learning among the issues monitored in the annual survey of the top ten issues of Chief Information Officers compiled by Educause. While this research cannot answer definitively whether technology is that silver bullet, it does attempt to model the factors which affect faculty technology use. In other words, it investigates how technology comes to be used by faculty, but not whether it achieves all that has been ascribed to it. 


\section{REVIEW OF LITERATURE}

\section{Data on Faculty Use of Technology}

Current data on faculty technology use indicates that faculty are increasing their use of technology. In a 1998 survey by the National Education Association [7], 70\% of faculty had a computer at home, 25\% had been involved with distance education, and $27 \%$ had a web site for their classes. It is very likely that these figures have increased to higher levels as use of course management software (CMS) - such as WebCT, Blackboard, or others that provide course materials and activities online-increased from $14.7 \%$ of the institutions answering the Campus Computing survey in 2000 to $33.6 \%$ of the institutions doing so in 2003 [8, p. 7). Two-thirds of the faculty in the University of Wisconsin system reported increased use of a CMS [9]. But other data paint a picture of faculty who are less involved in technology. For example, while $80 \%$ of public four-year institutions had course management systems (e.g., WebCT, Blackboard) in 2001, only $20 \%$ of courses taught by faculty used these systems [10]. Contrast these data with more recent data from the 2004 NSOPF that indicates $82 \%$ of faculty use email but only $50 \%$ used websites in their teaching. These data indicate an increasing, although not universal, use of various technologies by faculty. If faculty use of technology is to be encouraged, it is necessary to know what factors influence their use of websites in teaching. In other words, more research is needed to clarify their use of these new tools in professional activities.

\section{Demographics and Workload}

Because faculty technology use has been promoted as a "silver bullet," it is therefore important to understand which faculty come to use technology and the role of workload. Age and gender are widely thought to influence the use of technology. In national studies of the U.S. population, the Pew Internet and American Life Project have documented continuing differences in Internet use, but also a narrowing or elimination of those differences. Younger individuals use the Internet more frequently and more of them log in than older Americans [11]. However, for some specific activities (use email, get news, online purchasing), the different age groups are not that different. For example, $88 \%$ and $94 \%$ of Gen Y (18-28 year olds) and Leading Boomers (51-59) use email, 72\% and 74\% (respectively) get news online, and $68 \%$ and $67 \%$ (respectively) make online purchases. Males use online resources more than females, although black women and women under 30 exceeded their male peers in Internet use [12]. Women, however, are more "enthusiastic" [12, p. 1] online communicators, while men are more likely to perform transactions online, such as purchases and banking. In any case, it is clear that the genders are closing the earlier gap in Internet use. Given these research results, perhaps male and female higher education faculty are also becoming more alike in their use of technologies.

The impact of technology on workload has been amply documented [13,14]. Workload increases through a number of processes, including learning new skills [15], spreading work time over a larger portion of the day because of increased use of email and course management systems [16]; keeping online courses up-to-date through continuous upgrading [15]; and increasing development time as learning goals ascend Bloom's learning taxonomy from knowledge to create [17]. In fact, for one individual, workload doubled [18] as preparation time increased as did one-to-one instruction; Brown [19] claimed a $40 \%$ to $50 \%$ workload increase; in another study, $76 \%$ of faculty surveyed spent more time preparing and delivering courses [20]. These results are duplicated on a larger scale: the National Center for Education Statistics [21] found that faculty teaching distance education courses actually had a higher teaching load (which may capture the higher teaching loads of community colleges where much distance education has occurred). In addition, faculty of distance education courses had higher average office hours and hours spent on student email per week [21]. 
An interesting insight into faculty perceptions can be drawn from studies on wholly online courses. Geith and Vignare [22] and Geith and Cometa [23] found that all of the surveyed faculty felt they spent more time when teaching online. However, when the researchers investigated the faculty's self-reported hours, only three of the nine online sections actually consumed more faculty time per student than more traditional courses. Five sections consumed about the same amount of faculty time and one section consumed less time. In a similar effort to understand why faculty believe technology increases their workload is Hislop's [24] study. Four faculty completed time logs while teaching two courses each-one online and one face-to-face-where both courses had the same curriculum. Instructional time did not differ much (333 hours online versus 347 hours face-to-face), but the online courses did take more time per student and interactions with students were spread out over more days in the week, rather than on the days when the class met [24]. It is interesting to see that the Geith et al. studies [22, 23] would indicate that faculty perceptions of how much time it takes to teach using technology are not reliable, but Hislop [24] would claim that faculty perceptions of time may be more credible when the analysis breaks down total time spent into per-student or other analyses. Or it may be that faculty perceptions about time spent online is different because they are also dealing with patterns of behavior or interaction that are different from earlier face-to-face experiences. Clearly, this is an area that requires further study.

Although the increases to workload seem to be sharp in the early stages (when learning new skills and developing new online resources occur), little research has been done on whether workloads decrease as faculty improve their skills and take advantage of a "learning curve." In this vein, Bartolic-Zlomislic and Bates [25] identified a rapid learning curve for faculty in three case studies of online programs that included time to learn the software to be used, how to design courses, and provide online instruction.

What is intriguing in most of the research on the relationship of technology and workload is that it is in one direction: in other words, technology increases faculty workload. Therefore, this study will focus on the causal relationship from teaching workload to technology use.

\section{Models of Faculty Technology Use}

The National Survey of Postsecondary Faculty (NSOPF:04) presents an opportunity to model faculty technology use by using the variables included in this national database. This dataset includes demographic variables of interest as well as several variables capturing workload, which seemed important for analyzing faculty technology use based on the research literature already reviewed. In other words, it is the best national database for this research and it has the further advantage of moving beyond the one-institution studies so prevalent in earlier research.

In two previous studies, Meyer and Xu [1] and Xu and Meyer [2] used NSOPF:99 and NSOPF:04 data to identify the factors that influenced faculty use of technology in their teaching. In the first study [1], hierarchical multiple regression analysis found that individual factors with a statistically significant relationship to faculty technology use included gender, age, highest degree type, teaching load, and research productivity [1]. Younger faculty, faculty with doctorates, and faculty with higher teaching loads were found to use email and the web relatively more in their teaching. Faculty with higher research productivity were found using email more often than websites. One limitation of the study was that interactions among variables were not investigated.

In the second study [2], institutional factors such as the institutional expenses, student full-time equivalent enrollments, faculty/student ratios were investigated along with individual factors. By including both sets of variables (a total of 40 separate variables) and using Bayesian networks to examine relationships among variables, the analysis resulted in a finding that differences in technology use were apparent for 
faculty from different academic disciplines and for faculty employed by institutions of different Carnegie types. The most interesting results indicated that several variables capturing teaching (teaching as the individual's principal activity, student contact hours, percent time teaching, student credit hours taught) had significant and independent influences on technology use.

One consistent finding from both of these studies was the significant relationship between faculty teaching load and faculty technology use. With Bayesian analysis suggesting that teaching loads impact technology use, could it be that higher teaching loads send faculty members looking for technologies to use in order to do their job? This seems inconsistent with the literature on how technologies increase faculty workload, but both the importance and strength of this relationship indicate that in-depth investigation is needed into the causal relationships between workload and technology used in light of other related factors. Hence, this study tests a model that establishes the causal relationships between factors, including workload, influencing faculty technology use.

\section{Proposed Causal Model}

The causal model clarifies how individual and institutional factors - already found to be influential in Xu and Meyer [1] and Meyer and $\mathrm{Xu}$ [2] —interact and impact faculty use of technology in teaching. The proposed model is based primarily on these two studies. Rather than being a full-blown theory, the model (shown in Figure 1) is an abstraction that describes the probable causal relationships among significant factors that determine faculty use of technology. The plausibility and validity of the proposed model will be evaluated with the 2004 NSOPF data.

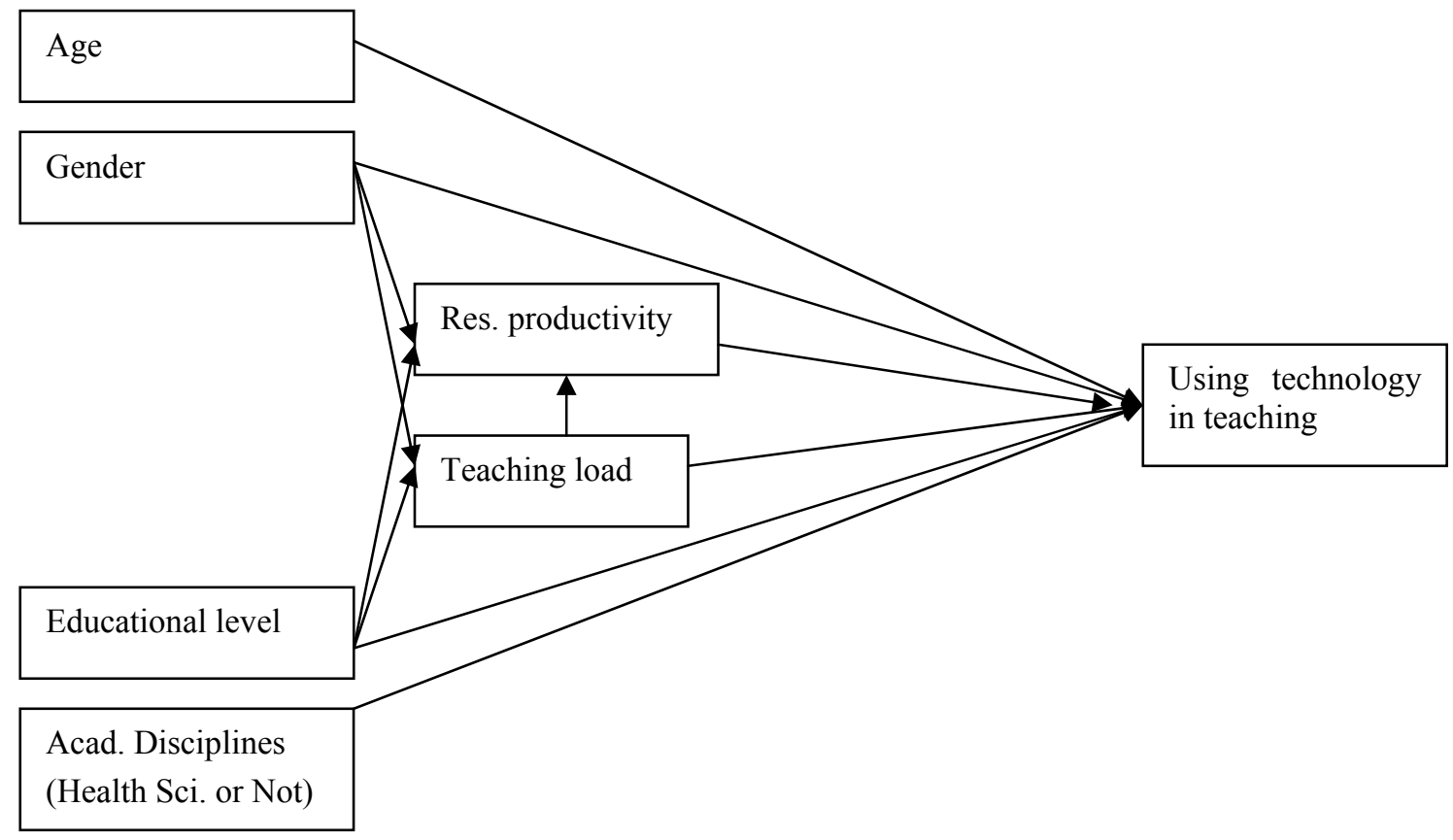

Figure 1. Proposed Causal Model of Faculty Technology Use in Teaching

With faculty technology use in teaching as the outcome variable, the proposed model suggests that there are direct effects from age, gender, education level, and academic discipline on this output measure. In addition to the direct effects, gender and educational level will have an indirect effect on technology use 
through teaching load and research productivity, given that many studies have found that female faculty have heavier teaching loads, which leave them with less time to conduct research [26, 27]. Academic disciplines are related to faculty technology use [1], since some disciplines (e.g., health fields) had distinctive patterns of technology use in comparison to other disciplines (e.g., business, education). The model recognizes the impact of teaching load on research productivity, but not the reverse. The reverse relationship (that research productivity impacts teaching load) is theoretically viable, but so far has not been borne out by earlier analyses. The model also recognizes the critical organizing role of teaching load in its effect on technology use as an intermediary of gender and education level as well as having an independent influence.

Although a number of institutional influences on technology use (i.e., appropriations, enrollment size) were evaluated in [2], only the Carnegie classification of institutions was found to explain variations in technology use in teaching. However, rather than incorporate all Carnegie types into this model, the proposed model was evaluated separately for faculty in Research I institutions and compared to faculty in community colleges. In the NSOPF data, the 1994 and 2000 Carnegie classifications are available. The Research I institutions are classified in terms of the level of research activity, which is measured by factors including, among others, research and development expenditures and number of doctoral programs. Community colleges are two-year institutions that mainly confer certificates or associate's degrees (For more information, please visit http://www.carnegiefoundation.org/classifications/). Because of the distinct academic missions, faculty responsibilities are somewhat different. Research I institutions emphasize faculty research as well as teaching and service, and community colleges predominantly stress teaching $[28,29]$. These two institutional types were chosen to focus on whether different expectations for faculty would play a role in faculty use of technology in teaching. How the model fits the two different faculty samples can shed more light on the causal effects between factors as well as the validity of the proposed model across institution types.

\section{METHODOLOGY}

\section{A. Data Source}

For this study, faculty members were selected if their principal activity was either teaching or research from the NSOPF:04 data. NSOPF:04 is the fourth national survey of postsecondary faculty sponsored by the National Center of Educational Statistics (NCES) since 1988. Even though the questions stay fairly consistent with minor modifications across surveys, a different sample of faculty was selected from the national pool in each survey. In the 2004 implementation of the survey, the original sample consisted of approximately 1,070 postsecondary institutions and more than 34,300 individuals employed in those institutions. The weighted response rate is $76 \%$ for the faculty survey. NSOPF surveys used complex sampling procedures including multi-level stratification and unequal probability selection of individuals. Following the discussion on data weighting of complex survey samples by Thomas and Heck [30], the data were weighted in both descriptive and inferential analysis. After data preprocessing, 2,748 faculty members from Research I institutions and 3,112 faculty from community colleges were included in the analysis.

\section{B. Variables}

The research objective is to propose and validate a causal model of factors determining faculty use of technology in teaching. Because the NSOPF:04 data showed that $82 \%$ of faculty members used email in their teaching [2], it is fair to conclude that email use has become the norm among higher education faculty. Thus, email use is not considered as an indicator of faculty adaptation of technology in this study. 
Rather, the outcome variable capturing technology use will focus on the variable titled "website for any instructional duties" (coded as 0 for No, 1 for Yes). The original item in NSOPF:04 is worded in this way:

Did you have one or more web sites for any of your teaching, advising, or other instructional duties? (Web sites used for instructional duties might include the syllabus, readings, assignments, and practice exams for classes; might enable communication with students via listservs or online forums; and might provide real-time computer-based instruction) [31, p. 23].

Table 1 presents the sample's distribution of faculty use of websites in teaching by gender and highest degree types. It shows that $61.6 \%$ of faculty members in Research I institutions used websites in their teaching, while only $39.1 \%$ of faculty in community colleges did so.

Table 1. Faculty Use of Website in Teaching by Gender and Highest Degree Type (Weighted)

\begin{tabular}{|c|c|c|c|c|c|c|}
\hline \multirow{2}{*}{ Highest degree } & \multicolumn{2}{|r|}{ Male } & \multicolumn{2}{|c|}{ Female } & \multicolumn{2}{|r|}{ Total } \\
\hline & Count & $\%$ using website & Count & $\%$ using website & Count & $\%$ using website \\
\hline & \multicolumn{6}{|c|}{ Research I institutions } \\
\hline Doctoral & 1520 & $67.0 \%$ & 585 & $63.3 \%$ & 2105 & $65.9 \%$ \\
\hline Master's & 192 & $49.3 \%$ & 194 & $49.4 \%$ & 386 & $49.3 \%$ \\
\hline $1^{\text {st }}$ professional & 143 & $41.1 \%$ & 60 & $49.5 \%$ & 203 & $43.6 \%$ \\
\hline Bachelor's & 30 & $53.3 \%$ & 25 & $38.7 \%$ & 55 & $46.6 \%$ \\
\hline \multirow[t]{2}{*}{ Total } & 1885 & $63.0 \%$ & 863 & $58.5 \%$ & 2748 & $61.6 \%$ \\
\hline & \multicolumn{6}{|c|}{ Community colleges } \\
\hline Doctoral & 297 & $48.2 \%$ & 162 & $51.9 \%$ & 459 & $49.5 \%$ \\
\hline Master's & 973 & $38.1 \%$ & 1034 & $41.3 \%$ & 2007 & $39.8 \%$ \\
\hline $1^{\text {st }}$ professional & 55 & $34.0 \%$ & 36 & $37.4 \%$ & 92 & $35.3 \%$ \\
\hline Bachelor's & 312 & $28.9 \%$ & 242 & $28.8 \%$ & 554 & $28.9 \%$ \\
\hline Total & 1637 & $38.0 \%$ & 1475 & $40.3 \%$ & 3112 & $39.1 \%$ \\
\hline
\end{tabular}

Age is faculty members' biological age at the time of data collection (2003-04); gender is coded as 1 for male and 2 for female. To keep a parsimonious model structure, disciplines are simplified into a binary variable, health science disciplines (coded as 1) versus non-health-sciences disciplines (coded as 0), because faculty in health science disciplines were found to have distinct patterns from those in other academic areas when it comes to using technology in teaching [1,2]. Educational level is measured by highest degree type, which includes doctoral, master's, first professional, and bachelor's degrees (coded as $4,3,2$, and 1, respectively). A few measures of teaching load were available in the NSOPF data, but "total student credit hours" was used in this study because increases in either the number of classes or the class sizes generally translate into an increase in teaching loads.

Last, because the causal model is a snapshot of faculty technology use at a certain point in time, it was decided to use research productivity in the last two years rather than career total research productivity. Measures of research productivity include the number of publications in juried journals, non-juried journals, books, book reviews, and presentations. It is difficult to justify eliminating any of these measures because different disciplines place different importance on them. Thus, an exploratory factor analysis (EFA) procedure was done to combine these variables of scholarly productivity into one more reliable measure of productivity. To be specific, one underlying factor was extracted that has an eigenvalue greater than 1 using a principal-components method. The scree plot also confirmed the singlefactor structure because the extracted factor was separated by a clear "elbow" from the others that had 
eigenvalues lower than 1 . No rotation was needed to simplify the structure because only one factor was retained. Thus, the scores of the extracted factor, accounted for $36.4 \%$ of the total variance, was used as the measure of research productivity in the study.

\section{Analytical Methods}

The data were prepared in SPSS first and imported into LISREL 8.7 to perform path analysis by reconstructing the covariance matrices through maximum likelihood estimation and validate the proposed causal structure of faculty technology use. Separate path analyses were run for faculty in Research I universities and in community colleges; fit indices were examined for each model and parameter estimates studied. Then, a multi-group path analysis was conducted by imposing a cross-group equality constraint on the path estimates to determine whether the model direct effects differ significantly for faculty in Research I or Community College institutions. Maximum likelihood function was used to estimate the model parameters. Multiple model fit indices are discussed below. Since the available faculty samples are relatively large, $\alpha=.01$ is used for tests of significance.

\section{RESULTS}

\section{A. Overview of Results}

Figure 2 shows the final path model of faculty technology use. In the process of path modeling, the direct effect from research productivity to technology use was removed due to non-significance. Also, an indirect effect was added from health science disciplines to faculty use of technology through teaching load as a result of analysis and further consideration of how teaching in the health science disciplines at research institutions may depend on technology to a lesser extent than other disciplines. This is an interpretation of the results that must be followed up with more detailed research. Statistically, the added path is supported by the single degree LaGrange-Modifier-based modification index that shows that the model $\chi^{2}$ decreased by 8.40 to 11.43 with a reduction in the degrees of freedom by 1 . In Figure 2, each path is marked with two numbers: the path coefficient (beta weight) for Research institution faculty before the slash (/) and the path coefficient for community college faculty after the slash. The standardized direct, indirect, and total effects of each variable on faculty use of websites are summarized in Table 2. In this section, the two models are presented separately. For each model, the fit is measured by four indices: $\chi^{2}$ coefficient, root-mean-square error (RMSEA), standardized root mean square residual (SRMR), and comparative fit index (CFI). Note that dozens of model fit indices have been made available in LISREL. In general, they fall in three categories. First, absolute indices evaluate the overall discrepancy between observed and model-implied variance/covariance matrices; $\chi^{2}$ and SRMR fall under this category. For good model fit, $\chi^{2}$ is expected to be non-significant, although it may not be the case in many studies because it is a statistic that is very sensitive to sample size. SRMR needs to be lower than .08 for acceptable models. Second, incremental indices evaluate a model's absolute or parsimonious fit relative to the null model. CFI is one of them and must have a value greater than .95 for good model fit. Third, parsimonious indices evaluate the overall discrepancy between observed and model-implied variance/covariance matrices while taking into account the simplicity of the model structure. RMSEA belongs to this group and a value lower than .06 is desired [32]. The four indices reported in this article are selected based on a discussion in McDonald and Ho [33] and followed examples in other published SEM studies in higher education research. In addition to fit evaluation of the models for Research I institutions and community colleges separately, at the end of this section, the similarities and differences of the two models are also briefly discussed based on the multi-group analysis. 


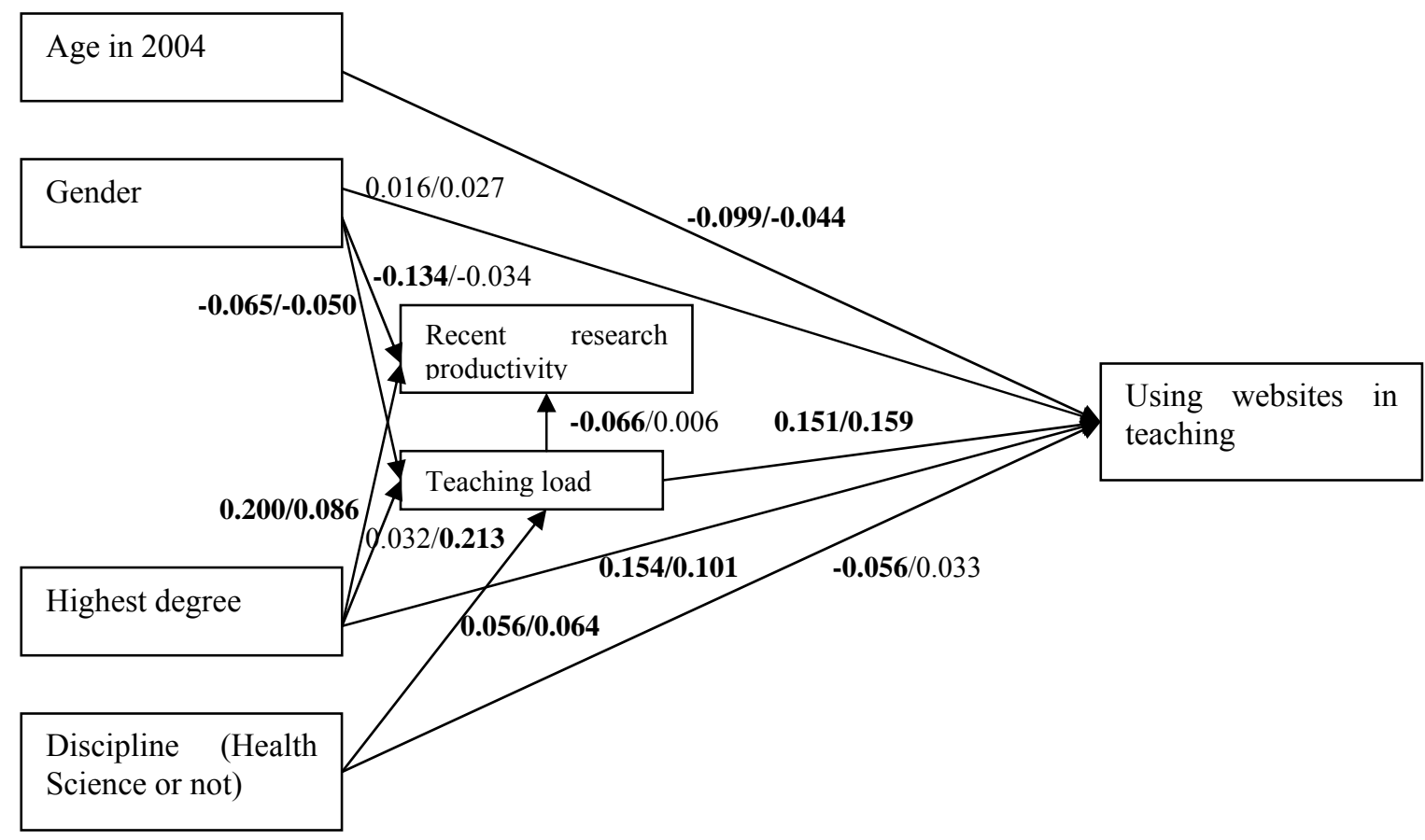

Figure 2. Path Analysis Model of Factors Influencing Faculty Technology Use

Notes. 1. The numbers marked on each path are "path coefficient for faculty in Research institutions/path coefficient for faculty in community colleges".

2. Numbers in bold indicate statistical significance at $\alpha=.01$.

3. $\mathrm{R}^{2}$ for teaching load, recent research productivity, and using website in teaching is $.008, .063$, and .038 , respectively for faculty in Research I institutions; and .049, .009, and .044, respectively for faculty in community colleges.

Table 2. Direct and Indirect Effects

\begin{tabular}{|c|c|c|c|c|c|c|}
\hline \multirow[b]{3}{*}{ Variables } & \multicolumn{6}{|c|}{ Standardized estimates } \\
\hline & \multicolumn{3}{|c|}{$\begin{array}{c}\text { Faculty in } \\
\text { Research I universities }\end{array}$} & \multicolumn{3}{|c|}{$\begin{array}{c}\text { Faculty in } \\
\text { community colleges }\end{array}$} \\
\hline & $\begin{array}{l}\text { Direct } \\
\text { effects }\end{array}$ & $\begin{array}{l}\text { Indirect } \\
\text { effects }\end{array}$ & $\begin{array}{l}\text { Total } \\
\text { effects }\end{array}$ & $\begin{array}{l}\text { Direct } \\
\text { effects }\end{array}$ & $\begin{array}{l}\text { Indirect } \\
\text { effects }\end{array}$ & $\begin{array}{l}\text { Total } \\
\text { effects }\end{array}$ \\
\hline Age & -.099 & & -.099 & -.044 & & -.044 \\
\hline Gender & .016 & -.010 & .006 & .027 & -.008 & .019 \\
\hline Highest degree & .154 & .005 & .159 & .101 & .034 & .135 \\
\hline H.S. disciplines & -.056 & .008 & -.047 & .033 & .010 & .044 \\
\hline Teaching load & .151 & & .151 & .159 & & .159 \\
\hline Recent research productivity & & & & & & \\
\hline
\end{tabular}

Note. Numbers in bold indicate statistical significance at $\alpha=.01$. 


\section{B. Path Analysis Model for Faculty in Research I Universities}

The path model of faculty use of websites in teaching has a RMSEA of approximately 0.026 , which is nonsignificant $(p=0.99)$. The value of this index suggests an excellent fit of the proposed causal model to the observed data. The $\chi^{2}$ coefficient is 11.43 with $d f=4$ and $p=0.022$; given the large sample size, this is another positive sign of good model fit. The SRMR of this model is 0.012 , which further confirms the model fit from the perspective of average magnitude of residuals. The fourth fit index, CFI $=0.99$, also means the models fit the data quite well.

With the model goodness of fit confirmed, the path coefficients between the predictor and predicted variables show that the strongest predictor of faculty technology use is the highest degree type (0.154), although the indirect effect of highest degree on technology use through teaching load is not significant. Increase in teaching load (0.151) contributes significantly to greater use of websites in teaching. Age is also a significant predictor for technology use (-0.099), suggesting that older faculty are less likely to use the web while teaching. Faculty in the health sciences have a relatively higher teaching load (.056), but the indirect effect of discipline on technology use is weak (0.008). Given that discipline had a direct effect on website use (-.056), the total effect shows that faculty in health science disciplines use websites for teaching purposes significantly less than those in non-health-science disciplines. Gender is not a significant predictor of technology use (-.006). It is worth nothing that this model suggests that female faculty members had significant lower teaching loads (-0.065) and fewer number of publications than their male colleagues in the last two years $(-0.134)$, while increased teaching load is found to lower research productivity $(-0.066)$. Overall, $3.8 \%$ of the variance in faculty use of websites is accounted for by this path model.

\section{Path Analysis Model for Faculty in Community Colleges}

The same model structure explains community college faculty use of websites given that the model goodness of fit indices are RMSEA $=0.024(p=1.00), \chi^{2}=11.43(d f=4, p=0.027)$; SRMR $=0.011$, and CFI $=0.99$. However, the parameter estimates reveal that the magnitude of impact exerted by individual factors on faculty use of technology in this model is different from the model for faculty in Research I institutions. The strongest predictor of faculty technology use is teaching load (0.159): heavier teaching loads appear to drive professors to increase use of websites in teaching. The second strongest predictor is highest degree (0.101), indicating that faculty with higher education levels use technology more often. Older faculty use websites less in teaching $(-0.044)$. Health science disciplines have a nonsignificant direct effect on technology use. However, combined with an indirect effect through teaching load, being in health science disciplines means community college faculty actually use more technology than their colleagues in other disciplines (0.044). Again, gender is not a significant predictor of technology use (0.019). Contradictory to earlier studies, female faculty actually had lighter teaching loads (-0.050); though, unlike faculty in Research I institutions, recent research productivity is comparable for both males and females for community college faculty. This may be due to the community college's lower emphasis on research for faculty, which equalizes the demand for research productivity for all faculty. Finally, possessing a higher degree meant heavier teaching loads (0.213) and more research productivity (0.086), but there is not a significant relationship between teaching load and research productivity. Overall, 4.4\% of the variance in faculty use of websites is accounted for by this path analysis model.

\section{Multi-Group Path Analysis}

The same model structure appears to explain faculty technology use quite well in the two different institution types. Nonetheless, differences in path coefficients and explained effects warrant further examination of the cross-group model fit. Thus, a multi-group path analysis was run, in which crossgroup equality constraints were imposed on the path estimates to determine whether the direct effects in 
the unconstrained models, as previously discussed, differ by Carnegie type (Research vs. Community College). The analysis shows that the goodness-of-fit for the constrained models is substantially worsened $($ RMSEA $=0.257$; SRMR $=0.21)$ when the two unconstrained models are compared. The poor fit of the cross-group model provides further evidence that observed differences in the parameter estimates and effects between the two unconstrained models are significant and that the factors driving faculty use of technology in teaching interact differently for faculty in Research I institutions and for faculty in community colleges as observed in the two unconstrained models.

\section{DISCUSSION}

This analysis has produced some intriguing results. First, the model as proposed and then refined appears reliable and sound. Age, degree level, discipline, and teaching load influence faculty use of technology, with teaching load being the greatest and most consistent influence. While the original model hypothesized an impact from research productivity to technology use in teaching, it was not maintained in the final model. This is difficult to explain without additional research being done that uses data collected to specifically explore this finding. It is possible that time spent on conducting research has little connection with using technology in teaching. Or, the relationship between research productivity and using the web in teaching could be obscured by contradicting forces. For example, experienced researchers may be able to put less effort into their teaching (assuming it takes some effort to employ websites in teaching) or perhaps the proliferation of course management systems make the use of the web in teaching easier and less time-consuming, therefore making it easier for busy researchers to use the web.

Another modification to the proposed model involved adding a link between academic discipline (health science or not) and teaching load. This is easy to understand considering teaching loads are different by discipline and health science faculty often work additional clinical or field rotations. It also adds to the importance of teaching load, which mediates all of the variables in the model except age.

There are differences between Research and Community College faculty and their use of websites in teaching. Discipline (health science or not) does not have significant direct effect on technology use for community college faculty, nor are gender and teaching load significant influences on research productivity, as befitting the community college's focus on teaching rather than research. Faculty in Research institutions produced significant relationships for disciplines (health science or not) on the use of websites in teaching as well as gender and teaching load on research productivity. In other words, the two types of institutions are different in their missions (i.e., their focus on teaching for community colleges versus teaching and research for Research institutions), and this difference is captured by the model. One of the reasons for retaining recent research productivity in the model is to capture its continuing importance for faculty in Research institutions, even if its impact on technology use is unproven.

There are many similarities between the two models, perhaps capturing some basic or foundational qualities of the faculty job that are true whether the faculty person is working at a Research institution or Community College. Age matters for technology use, with older faculty perhaps finding it more difficult to keep up with new technologies (which does not mean they are not willing or not able to learn). Highest degree also matters, as does teaching load. The more likely that faculty possess the doctorate and have a high teaching load, the more likely they will use websites in their teaching. But perhaps in contrast to early expectations that females used technologies less than males, gender did not have significant influence on faculty use of websites in teaching in either type of institution. 
In this study, as the faculty person's teaching workload increased, the use of websites in teaching also increased. This may be capturing a need of faculty to seek new ways of teaching as demands on them grow. This finding of the connection of teaching load to technology use should not be construed to imply we advocate increasing teaching loads to encourage greater technology use. This would be a dangerous misinterpretation. It is not clear if faculty with higher teaching loads choose to adopt the use of the web in order to achieve some efficiencies in the use of their time or to lighten their load, so to speak. Or, this relationship may capture institutional pressures to teach more and use more technology, perhaps in response to budget problems, a need to address enrollment growth, or pressure from institutional leaders. There may also be a natural limit to how much web use can be incorporated into a busy teaching load; while course management systems might alleviate this problem, there is a practical limit to how much any faculty can accomplish within a 24-hour day. In other words, without paying attention to teaching faculty how and when to apply technology so that technology can help relieve pressures on their time, realizing greater teaching productivity (in terms of increased courses and/or enrollments) may not occur [34].

But what should institutions do based on this model? Should they increase teaching loads and only hire young Ph.D.s? Clearly not. However, they may decide to research the causal relationships of teaching load or research productivity on technology use and explore the conditions that could affect this relationship. Perhaps there are differences based on institutional type (e.g., small private liberal arts institutions) or disciplines which have different expectations for using technologies to teach. Second, institutions may want to consider exploring whether policies on faculty workload are affecting technology use or if there is a limit to this relationship.

As for future research, this model is based on both literature and previous studies conducted on the NSOPF 1999 and 2004 datasets. It explains the causal relationships among the variables, and does so with good model fit indices. But because the variance in faculty technology use explained by the models is not satisfactory, we need to continue to explore other hypotheses that may fit the data equally well or better. It is important to remember that the current model was developed and confirmed using a single database (NSOPF:04). In order to confirm, modify, or refute this model, future research needs to use more recent data and/or collect additional data elements that could fill important holes in the model.

It will be important to explore other mitigating or preexisting variables that may better explain the relationships in the model. There is literature on the roles of barriers to faculty using technology, including a loss of face-to-face, live interaction with students [35,36] and a lack of support or assistance to learn and implement the technologies [13,35,36,37]. Because the NSOPF:04 database does not include variables that capture these barriers, they could not be included in the model.

Future research ought to also explore how faculty motivations to use technology modify relationships in the model. Faculty are motivated to use technology in order to reach new audiences $[35,36,38]$, to pursue an interest in learning new skills [36, 39], to enjoy the flexibility of the new approach [13, 35, 36, 39], and to stay up-to-date [35] and relevant [40]. Betts [41], Schifter [42, 43], and Rockwell et al. [14] explored the role of faculty's intrinsic and extrinsic motivations to use technology, and these motivations should be included in further research on the model in this research.

Furthermore, future research ought to explore the differences between Carnegie types and whether the individual's preference for teaching (or research) affects the institutional type they choose to work in and their willingness to use technology for teaching.

Finally, it is important for readers to keep in mind the limitations of this study when evaluating the findings. First, the causal model was generated using data from a national survey. Because the survey 
relied on self-reported information, the research questions were answered with limited depth and breadth. Second, the model proposed in this study is based on the authors' understanding of the literature and knowledge about faculty work. Nonetheless, readers need to be aware that, even though the models fit the data with good indices, there could be other competing models that statistically fit the data equally well or better. Further research is needed in this area.

\section{CONCLUSIONS}

So is faculty use of technology a silver bullet or not? Technology use is, as of 2004, widespread and almost universal for email. It is easy to understand why younger faculty use technology more than their counterparts, but it is less clear why teaching load influences technology use although it does so consistently despite different analytical approaches and statistical tools. The merits of this model lie in the extended understanding of factors influencing faculty technology use from personal level to institutional level (which includes differences resulting from discipline or institutional type), and statistically modeling their causal relationships that have not be done previously. It is worth noting that the final models are only one of the models that explained the data structure well, and there are possible alternatives that may explain faculty technology use equally well or even better thereby resulting in a higher $R^{2}$.

If technology was ever perceived as a silver bullet, it is a bullet whose trajectory is unknown, whose velocity is unknown, and whose arc and distance is unknown. In other words, while our understanding of the benefits of technology is emerging and we can state that technologies are certainly worthy tools, technology hardly qualifies for the status of a silver bullet that solves everything magically. Some problems it can help solve, although doing so will take effort, but solving all things will have to await the next silver bullet, if it exists.

\section{REFERENCES}

1. Xu, Y., \& K. A. Meyer. Factors explaining faculty technology use and productivity. The Internet and Higher Education 10(1): 41-52, 2007.

2. Meyer, K.A., \& Y. J. Xu. A Bayesian analysis of the institutional and individual factors influencing faculty technology use. The Internet and Higher Education 10(3): 184-195, 2007.

3. Oblinger, D. G. Educating the net generation, no date. Available online at https://www .msmc.la.edu/Include/learning resources/todays learner/OneDayv2-HO.pdf.

4. Woratschek, C. R., \& Lenox, T. L. Information Systems Entry-Level Job Skills: A Survey of Employers, 2002. Available online at http://isedj.org/isecon/2002/343a/ISECON.2002.Woratschek.txt.

5. Greer-Pitt, S. Distance learning: Silver bullet or educational apartheid? ERIC document ED466235, 2001.

6. Twigg, C. A. Is technology a silver bullet? Educom Review 31(2). Available online at https://www.educause.edu/pub/er/review/reviewArticles/31228.html.

7. National Education Association. Quality on the line. Washington, DC: Institute for Higher Education Policy, 2000.

8. Green, K. C. Campus Computing 2003. Encino, CA: Campus Computing Project, 2003.

9. Morgan, G. Faculty use of course management systems. ECAR Key Findings, 2003. Available online at http://net.educause.edu/ir/library/pdf/EKF/ekf0302.pdf.

10. Lynch, D. Professors should embrace technology in courses... The Chronicle of Higher Education, 48(19): B15-B16, January 18, 2002.

11. Fox, S. \& M. Madden. Internet use and email. Pew Internet and American Life Project, 2005. Available online at http://www.pewinternet.org/pdfs/PIP Generations Memo.pdf. 
12. Fallows, D. How women and men use the Internet. Pew Internet and American Life Project, 2005. Available online at http://www.pewinternet.org/PPF/r/171/report display.asp.

13. Betts, K. S. Factors influencing faculty participation in distance education in postsecondary education in the United States: An institutional study. Ph.D. diss. The George Washington University, Washington, DC, 1998.

14. Rockwell, S. K., J. Scheuer, S. J. Fritz, \& D. B. Marx. Incentives and obstacles influencing higher education faculty and administrators to teach at a distance. The Online Journal of Distance Learning Administration 2(4): 1999. Online at http://www.westga.edu/ distance/rockwell24.html.

15. Adria, M. \& T. Rose. Technology, preprocessing, and resistance-A comparative case study of intensive classroom teaching. Journal of Education for Business 80(1): 53-60, 2004.

16. Dziuban, C. D., J. C. Brophy-Ellison, \& J. Hartman. Faculty 2.0. Educause Review 42(5): 6277, 2007.

17. Brahler, C. J., N. S. Peterson, and E. C. Johnson. Developing on-line learning materials for higher education: An overview of current issues. Educational Technology \& Society 2(2): 1999. Available online at http://www.ifets.info/journals/2 2/jayne brahler.html.

18. Cavanaugh, J. Workload and compensation considerations for online faculty. Academic Leader 22(7): 2006. Available online at http://www.magnapubs.com/pub/magnapubs al/22 7/news 1598995-1.html

19. Brown, B. M. Digital classrooms: Some myths about developing new educational programs using the Internet. T.H.E. Journal, 1998. Available online at http://thejournal.com/articles/1406 2.

20. McKenzie, B. K., N. Mims, E. Bennett, \& M. Waugh. Needs, concerns and practices of online instructors. The Online Journal of Distance Learning Administration 3(3): 2000. Available online at http://www.westga.edu/ distance/ojdla/fall33/mckenzie33.html.

21. National Center for Education Statistics. Distance education instruction by postsecondary faculty and staff: Fall 1998 (NCES 2002-155), 2002. Washington, DC: U.S. Department of Education.

22. Geith, C., \& K. Vignare, K. Online degree programs: Service and cost. In J. Bourne and J.C. Moore (Eds.) Online Education, 203-211, 2001. Needham, MA: Sloan-C.

23. Geith, C., \& M. Cometa. Cost analysis results: Comparing distance learning and on-campus courses, 1999. Available online at http://www.rit.edu/ 609www/ch/faculty/CostStudy.PDF.pdf.

24. Hislop, G. W. Does teaching online take more time? Paper presented at $31^{\text {st }}$ ASEE/IEEE Frontiers in Education Conference, October, Reno, NV, 2001. Available online at http://fie.engrng.pitt.edu/fie2001/papers/1198.pdf.

25. Bartolic-Zlomislic, S., \& A. W. Bates. Investing in online learning: Potential benefits and limitations, 1999. Available online at http://bates.cstudies.ubc.ca/investing.html.

26. Park, S. M. Research, teaching, and service: Why shouldn't women's work count? In B. RopersHuilman (Ed.), Women in Higher Education: A Feminist Perspective (2 ${ }^{\text {nd }}$ Ed.), 285-308. Boston, MA: Pearson Custom Publishing, 2000.

27. Stack, S. Gender, children and research productivity. Research in Higher Education 45(8): 891920, 2004.

28. Thomas, S. L., and R. H. Heck. Analysis of large-scale secondary data in higher education research: Potential perils associated with complex sampling designs. Research in Higher Education, 42(5): 517-540, 2001.

29. Fairweather, J. S. Beyond the rhetoric: Trends in the relative value of teaching and research in faculty salaries. Journal of Higher Education 76(4): 401-422, 2005.

30. Fugate, A. L. Career stages of community college faculty: A qualitative analysis of their career paths, roles, and development. Community College Review 28(1): 1-22, 2000.

31. National Center for Education Statistics. Faculty questionnaire. National Study of Postsecondary Faculty, 2005. Available online at http://nces.ed.gov/surveys/nsopf/pdf/2004 Faculty Questionnaire.pdf.

32. Hu, L. T., and P. M. Bentler. Cutoff criteria for fit indexes in covariance structure analysis: Conventional criteria versus new alternatives. Structural Equation Modeling 6: 1-55, 1999. 
33. McDonald, R. P., \& M. R. Ho. Principles and practice in reporting structural equation analyses. Psychological Methods 7(1): 64-82, 2002.

34. Meyer, K. A. Online program capacity: Limited, static, elastic, or infinite? Planning for Higher Education 36(2): 52-63, 2008.

35. Berge, Z. L. Barriers to online teaching in post-secondary institutions: Can policy changes fix it? The Online Journal of Distance Learning Administration 1(2): 1998. Available online at http://www.westga.edu/ distance/Berge12.html.

36. Clay, M. Faculty attitudes toward distance education at the State University of West Georgia, 1999. Available online at http://www.westga.edu/ distance/attitudes.html.

37. McGee, P. A., \& V. Diaz. Wikis and Podcasts and Blogs! Oh, My! What is a faculty member supposed to do? Educause Review 41(5): 28-41, 2007.

38. Barron, A. E. \& C. Lyskawa. A review of tools for developing and managing online courses. Society for Information Technology and Teacher Education Annual: 163-165, 1998.

39. Mims, N. G., B. K. McKenzie, \& E. Kirby. How to simply involvement in on-line coursework. Society for Information Technology and Teacher Education Annual: 220-223, 1999.

40. Mims, N. G. Out of the ivory tower and into the chat rooms - are we giving in too much to technology? The Online Journal of Distance Learning Administration 2(3): 1999. Available online at http://www.westga.edu/ distance/mims23.html.

41. Betts, K. S. An institutional overview: Factors influencing faculty participation in distance education in postsecondary education in the United States: An institutional study. The Online Journal of Distance Learning Administration 1(3): 1998. Available online at http://www.westga.edu/ distance/betts13.html.

42. Schifter, C. Perception differences about participating in distance education. Online Journal of Distance Learning Administration 5(1): 2002. Available online at http://www.westga.edu / distance/ojdla/spring51/schifter51.html.

43. Schifter, C. C. Factors influencing faculty participation in distance education: A factor analysis. $E D$ at a Distance 13(1): 2000. Available online at http://www.usdla.org/ED _magazine/illuminactive/JAN00_Issue/Factors.htm.

\section{ABOUT THE AUTHORS}

Katrina A. Meyer, PhD is Associate Professor of Higher and Adult Education at the University of Memphis specializing in online learning and higher education. She is the author of Cost-efficiencies of Online Learning, a 2006 publication of the ASHE Higher Education Report Series. For over three years, she was Director of Distance Learning and Technology for the University and Community College System of Nevada. Prior to this, she served over 8 years as Associate Director of Academic Affairs for the Higher Education Coordinating Board in the state of Washington and was responsible for technology planning and policy related to online learning.

Yonghong Jade Xu, PhD is Assistant Professor of Educational Research at the University of Memphis. She teaches graduate-level statistics in the College of Education and specializes in quantitative research methodology. Her research interests include the quality of faculty work life in postsecondary institutions, women faculty in science and engineering, statistics teaching and learning, and large-scale data analysis with multivariate and data mining approaches. 


\title{
Perception Differences About Participating in Distance Education
}

Catherine Schifter, Associate Professor, College of Education, Temple University, Philadelphia, PA. catherine.schifter@temple.edu

\begin{abstract}
Non-traditional distance education is increasingly common in higher education. While many distance programs are separated into continuing education or adult education programs, infusion of distance education courses as options for traditional higher education students is beginning to take hold. (U.S. Department of Education, 1999, HERI, 1999) For this to be successful, faculty of the institution need to be part of the process, specifically in developing and teaching the courses.
\end{abstract}

The pedagogy of the faculty member in a distance education course changes from a teacher-centered approach to being student-centered (Strain, 1987; Beaudoin, 1990; 1998; Berge, 1998). In addition, "unbundling" of the faculty role is more and more recommended for distance education. (Paulson, 2002), but this is difficult for many faculty who are concerned about who then owns the course or copyright. Carnevale (2001) notes in a report in the Chronicle of Higher Education a recent AFT report that indicates concern over the practice of "unbundling" the traditional role of the professor by online courses creators. Unfortunately, research has indicated many faculty are not enthusiastic about participating in distance education (Olcott and Wright, 1995). Issues that have been noted as barriers to faculty participation include insufficient training, lack of applicability toward promotion and tenure, lack of release time, insufficient instructional and administrative support, minimal monetary compensation, and an expanded teaching load (Clark, 1993; Dillon and Walsh, 1992; Koontz, 1989; Olcott, 1991; 1992; 1993; Wagner and Elms, 1993; and Wolcott, 1993). Bower (2001) notes that for some faculty who teach distance courses the lack of direct interpersonal contact and feedback from students is a problem, given the fact that most faculty learn to teach face-to-face, or "hand-to-hand." (p. 2) Do these factors remain?

Taylor and White (1987), McKenzie (2000), and Seay, Rudolph and Chamberlain (2001) reported faculty preferred conventional face-to-face courses over distance teaching due to the degree of interpersonal contact available in each mode. Less interaction with the students led to less interest on the part of faculty to participate. Clark (1993) showed through a national survey that faculty support for distance courses was tempered by concern for quality of interaction, administrative support, and rewards. Betts (1998) demonstrated that the strongest motivating factors for faculty who participate in distance education are different from perceptions held by non-participating faculty and administrators of motivating factors for faculty participating. One question that does not seem to have received attention is whether there are differences in faculty attitudes by gender, age, faculty rank, and tenure status.

Faculty (distance education participators and non-participators) and administrators at a research extensive, state-related university were surveyed about (1) faculty use of technology in teaching, (2) motivating and inhibiting factors for participating in distance education, and (3) understanding of policies on distance education. This paper presents a factor analysis of the 46 motivating and inhibiting factors for distance education participation and an analysis of interaction between responses and level of participation in distance education, gender, age, faculty rank and tenure status. 


\title{
Methods
}

With permission from the author (Betts, 1998), this study used a modified version of a survey developed to identify factors that influence faculty participation in distance education (Betts, 1998). Minor modifications were made to address the institution for this study. The survey was distributed in to all fulltime faculty and twenty-five senior administrators, including all deans. After accounting for faculty on leave (paid or unpaid) from the university, the target faculty population totaled 1312. A total of 263 completed and usable surveys were returned for a response rate of $20 \%$, which could limit the external validity of the results. A total of eleven administrators returned the survey for a $44 \%$ response rate; however, only nine completed the sections on motivating and inhibiting factors.

The data was analyzed using the SPSS Statistical Package. First, the 29 motivating (Table 1) and 17 inhibiting (Table 2) factors were ranked according to mean scores and a factor analysis was used on all 46 factors to see how they grouped. An analysis of variance (ANOVA) was conducted on mean factor scores to determine significant differences by level of participation, gender, age range, faculty rank and tenure status. Four independent Chi-square analyses were run to test the null hypothesis that there was no relationship between level of participation and gender, age range, faculty rank or tenure status.

\section{Table 1: Motivating Factor List}

\author{
Personal motivation to use technology \\ Graduate training received \\ Opportunity for scholarly pursuit \\ Reduced teaching load \\ Opportunity to use personal research as a teaching tool \\ Requirement by department \\ Support and encouragement from dean or chair \\ Working conditions (e.g., hours, location) \\ Job security \\ Monetary support for participation (e.g., stipend, overload) \\ Expectation by university that faculty participate \\ Opportunity to develop new ideas \\ Visibility for jobs at other institutions/organizations \\ Professional prestige and status \\ Grants for materials/expenses \\ Support and encouragement from departmental colleagues \\ Intellectual challenge \\ Overall job satisfaction \\ Technical support provided by the institution \\ Career exploration \\ Credit toward promotion and tenure \\ Release time \\ Distance education training provided by the institution \\ Merit pay \\ Greater course flexibility for students \\ Opportunity to diversify program offerings \\ Ability to reach new audiences that cannot attend classes on campus \\ Opportunity to improve my teaching \\ Support and encouragement from institutional administrators
}


Concern about faculty workload

Negative comments made by colleagues about distance education teaching experiences

Lack of distance education training provided by the institution

Lack of support and encouragement from departmental colleagues

Lack of release time

Lack of professional prestige

Lack of technical background

Lack of support and encouragement from dean or chair

Lack of grants for materials/expenses

Concern about quality of courses

Lack of technical support provided by the institution

Lack of merit pay

Lack of support and encouragement from institution administrators

Lack of monetary support for participation (e.g., stipend, overload)

Concern about quality of students

Lack of salary increase

Lack of credit toward promotion and tenure

\section{Results}

Table 3 presents the demographic data about the respondents. While the survey was sent to full-time faculty, two respondents were part-time faculty and one person did not answer this item. Thirty-eight (14.4\%) faculty indicated they participated in distance education. For the purpose of this study, this group is called "participators" and those who did not indicated participating in distance education are called "non-participators."

\section{Table 3: Demographic information}

\begin{tabular}{|l|l|l|}
\hline Category & Number & Percentage \\
\hline Gender - male & 168 & $63.9 \%$ \\
\hline Gender - female & 94 & $35.7 \%$ \\
\hline Age $=<30$ years & 20 & $7.6 \%$ \\
\hline $\begin{array}{l}\text { Age }=30-45 \\
\text { years }\end{array}$ & 117 & $44.5 \%$ \\
\hline $\begin{array}{l}\text { Age }=45-60 \\
\text { years }\end{array}$ & 90 & $34.2 \%$ \\
\hline Age = > 60 years & 35 & $13.3 \%$ \\
\hline $\begin{array}{l}\text { Rank - Full } \\
\text { Professor }\end{array}$ & 126 & $47.9 \%$ \\
\hline $\begin{array}{l}\text { Rank - Associate } \\
\text { Professor }\end{array}$ & 74 & $28.1 \%$ \\
\hline $\begin{array}{l}\text { Rank - Assistant } \\
\text { Professor }\end{array}$ & 47 & $17.9 \%$ \\
\hline Rank - Instructor & 16 & $6.1 \%$ \\
\hline Status - Tenured & 186 & $70.7 \%$ \\
\hline $\begin{array}{l}\text { Status - } \\
\text { Untenured }\end{array}$ & 74 & $28.3 \%$ \\
\hline
\end{tabular}


A total of eleven administrators returned the self-study survey: six deans, two vice presidents, one vice provost, one associate dean, and one acting assistant dean. Of the eleven, nine completed all the sections, including those on motivating and inhibiting factors.

Faculty and administrators were asked to rate from 5 to 1 ( 5 = strongly agree; $1=$ strongly disagree) to what extent they believed 29 factors had motivated, or would motivate, faculty to participate in distance education and 17 factors had inhibited, or would inhibit, faculty from participating in distance education. A factor analysis of all 46 factors (motivating and inhibiting) rendered four scales, showing distinct factor relationship patterns. In addition, an overall "motivation" scale was calculated for the 29 motivating factors, and an overall "inhibiting" scale was calculated for the 17 inhibiting factors. These six scales were used in further analysis of the response.

Scale 1 was labeled "Intrinsic motives” and had an Alpha coefficient of .9123. The following factors grouped into this scale:

- Intellectual challenge

- Opportunity to diversify program offerings

- Opportunity to develop new ideas

- Overall job satisfaction

- Opportunity to improve my teaching

- Greater course flexibility for students

- Personal motivation to use technology

- Ability to reach new audiences that cannot attend classes on campus

- Opportunity for scholarly pursuit

- Opportunity to use personal research as a teaching tool

Scale 2 is labeled "Personal needs" and has an Alpha coefficient of .8956. The following items grouped into "personal needs":

- Release time

- Credit toward promotion and tenure

- Merit pay

- Monetary support for participation (e.g., stipend, overload)

- Visibility for jobs at other institutions/organizations

- Lack of credit toward tenure and promotion

- Grants for materials/expenses

- Reduced teaching load

- Working conditions (e.g., hours, location)

- Professional prestige and status

- Job security

- Career exploration

- Graduate training received

Scale 3 is labeled "Inhibitors" and has an Alpha coefficient of .8878. The following items grouped into "inhibitors":

- Lack of release time

- Lack of support and encouragement from institution's administrators

- Lack of merit pay 
- Lack of support and encouragement from departmental colleagues

- Lack of monetary support for participation (e.g., stipend, overload)

- Lack of support and encouragement from dean or chair

- Lack of grants for materials/expenses

- Lack of technical support provided by the institution

- Lack of salary increase

- Lack of distance education training provided by the institution

- Lack of professional prestige

- Concern about faculty workload

- Negative comments made by colleagues about distance education teaching experiences

- Concern about quality of courses

- Concern about quality of students

Scale 4 is labeled "Extrinsic motives" and has an Alpha coefficient of .8440. The following items grouped into "extrinsic motives":

- Expectation by university that faculty participate

- Requirement by department

- Support and encouragement from dean or chair

- Support and encouragement from departmental colleagues

- Distance education training provided by the institution

- Support and encouragement from institution's administrators

- Technical support provided by the institution

- Lack of technical background

The means of each the four scales and each individual factor (motivating and inhibiting) were analyzed using an ANOVA to test significant differences between level of faculty participation in distance education (participate, not participate). Significant differences were found for nine motivating (M) factors and one inhibiting (I) factor. The results are found in Table 3. Overall, distance education participating faculty rated intrinsic motives higher (M1 and M26), while non-participating faculty rated higher personal needs (M4, M10, and M22), inhibitors (I3), and extrinsic motives (M19 and M23).

Table 4. ANOVA calculated significant differences found between DE participation and motivating or inhibiting factors

\begin{tabular}{|l|l|l|r|r|}
\hline Factor & Par. mean score & $\begin{array}{l}\text { Non-par. mean } \\
\text { score }\end{array}$ & F score & Significance level \\
\hline M1 (Scale 1) & 4.39 & 3.84 & 6.6307 & $\mathrm{p}<.01$ \\
\hline M4 (Scale 2) & 2.58 & 3.33 & 9.0709 & $\mathrm{p}<.01$ \\
\hline M10 (Scale 2) & 2.86 & 3.55 & 8.1869 & $\mathrm{p}<.01$ \\
\hline M19 (Scale 4) & 3.33 & 3.85 & 5.5393 & $\mathrm{p}<.01$ \\
\hline M20 (Scale 2) & 3.31 & 2.84 & 4.2912 & $\mathrm{p}<.05$ \\
\hline M22 (Scale 2) & 2.86 & 3.37 & 3.8999 & $\mathrm{p}<.05$ \\
\hline M23 (Scale 4) & 2.81 & 3.36 & 5.4578 & $\mathrm{p}<.05$ \\
\hline M26 (Scale 1) & 3.97 & 3.54 & 4.2564 & $\mathrm{p}<.05$ \\
\hline I3 (Scale 3) & 3.36 & 3.82 & 4.9078 & $\mathrm{p}<.05$ \\
\hline
\end{tabular}


The same analysis was conducted including administrators' means. Significant differences were found for twelve motivating factors, two inhibiting factors, and Scale 2 (Personal needs). The results are found in Table 4.

Table 5. ANOVA calculated significant differences found between administrators and DE participation with motivating or inhibiting factors and the four scales

\begin{tabular}{|l|l|l|l|r|r|}
\hline Factor & Par* mean & $\begin{array}{l}\text { Non-par* } \\
\text { mean }\end{array}$ & Admin mean & F score & Significance level \\
\hline M1 (Scale 1) & 4.39 & 3.84 & 4.56 & 4.6897 & $\mathrm{p}<.01$ \\
\hline M4 (Scale 2) & 2.58 & 3.33 & 3.78 & 5.3317 & $\mathrm{p}<.001$ \\
\hline M5 (Scale 1) & 3.09 & 3.38 & 4.25 & 3.0927 & $\mathrm{p}<.05$ \\
\hline M10 (Scale 2) & 2.86 & 3.55 & 4.44 & 6.7877 & $\mathrm{p}<.001$ \\
\hline M16 (Scale 4) & 3.31 & 3.03 & 4.11 & 4.1479 & $\mathrm{p}<.05$ \\
\hline M19 (Scale 4) & 3.33 & 3.85 & 4.33 & 3.7907 & $\mathrm{p}<.05$ \\
\hline M20 (Scale 2) & 3.31 & 2.84 & 3.67 & 3.7308 & $\mathrm{p}<.05$ \\
\hline M21 (Scale 2) & 3.00 & 2.85 & 4.44 & 5.7116 & $\mathrm{p}<.01$ \\
\hline M22 (Scale 2) & 2.86 & 3.37 & 4.44 & 5.0845 & $\mathrm{p}<.01$ \\
\hline M23 (Scale 4) & 2.81 & 3.36 & 4.11 & 4.6789 & $\mathrm{p}<.01$ \\
\hline M24 (Scale 2) & 2.91 & 3.41 & 4.11 & 3.3579 & $\mathrm{p}<.05$ \\
\hline I12 (Scale 3) & 3.06 & 3.29 & 4.22 & 3.3774 & $\mathrm{p}<.05$ \\
\hline I17 (Scale 2) & 3.17 & 3.02 & 4.11 & 3.0763 & $\mathrm{p}<.05$ \\
\hline $\begin{array}{l}\text { Two (Personal } \\
\text { needs) }\end{array}$ & 2.90 & 3.10 & 3.85 & 4.3176 & $\mathrm{p}<.05$ \\
\hline
\end{tabular}

* "Par" represents faculty 'participant' in distance education; "Non-par" represents faculty non-participants in distance education

Very significant differences ( $\mathrm{p}<.001$ ) were found between faculty (participators and non-participators) and administrators on "reduced teaching load" (M4) and "monetary support for participation" (M10). The administrators rated these factors much higher than either faculty group, and the non-participators rated both higher than the participator group. It is of interest to note the differences between groups on issues of "personal motivation to use technology" (M1), "credit toward promotion and tenure" (M21), "release time" (M22), and "distance education training provided by the institution" (M23). Personal motivation was rated higher by participating faculty than non-participants, while the other three factors were rated higher by non-participating faculty. The data shows administrators rate these factors significantly differently than faculty, whether participators in distance education or not; however, there were only 9 administrators who completed this section of the survey.

Using the mean scores for faculty, an ANOVA was calculated for differences in individual factors (motivating $=\mathrm{M}$, inhibiting $=\mathrm{I}$ ) or in the 4 scales by gender. Significant differences were found in 18 motivating factors, nine inhibiting factors, and four scales. Results are found in Table 5.

Table 6: ANOVA calculated significant differences found for gender of respondent and motivating or inhibiting factors

\begin{tabular}{|l|l|l|r|r|}
\hline Factor & Male & Female & F score & Significance level \\
\hline M2 (Scale 2) & 2.20 & 2.60 & 5.3448 & $\mathrm{p}<.05$ \\
\hline M6 (Scale 4) & 2.48 & 2.90 & 5.2045 & $\mathrm{p}<.05$ \\
\hline M7 Scale 4) & 3.28 & 3.75 & 8.1996 & $\mathrm{p}<.01$ \\
\hline M9 (Scale 2) & 2.71 & 3.13 & 4.8586 & $\mathrm{p}<.05$ \\
\hline M11 (Scale 4) & 2.83 & 3.32 & 9.7475 & $\mathrm{p}<.01$ \\
\hline M12 (Scale 1) & 3.77 & 4.09 & 4.3276 & $\mathrm{p}<.05$ \\
\hline M13 (Scale 2) & 2.68 & 3.05 & 4.2798 & $\mathrm{p}<.05$ \\
\hline
\end{tabular}




\begin{tabular}{|l|l|l|r|r|}
\hline M16 (Scale 4) & 2.91 & 3.37 & 7.8714 & $\mathrm{p}<.01$ \\
\hline M19 (Scale 4) & 3.61 & 4.01 & 5.5773 & $\mathrm{p}<.05$ \\
\hline M20 (Scale 2) & 2.76 & 3.19 & 5.9128 & $\mathrm{p}<.05$ \\
\hline M21 (Scale 2) & 2.65 & 3.29 & 10.5251 & $\mathrm{p}<.01$ \\
\hline M22 (Scale 2) & 3.13 & 3.53 & 4.0232 & $\mathrm{p}<.05$ \\
\hline M23 (Scale 4) & 3.01 & 3.69 & 14.6315 & $\mathrm{p}<.000$ \\
\hline M25 (Scale 1) & 3.50 & 3.88 & 5.3938 & $\mathrm{p}<.05$ \\
\hline M26 (Scale 1) & 3.47 & 3.81 & 4.4079 & $\mathrm{p}<.05$ \\
\hline M28 (Scale 1) & 3.67 & 4.04 & 5.3034 & $\mathrm{p}<.05$ \\
\hline M29 (Scale 4) & 3.00 & 3.41 & 5.2209 & $\mathrm{p}<.05$ \\
\hline I3 (Scale 3) & 3.60 & 4.00 & 6.6160 & $\mathrm{p}<.01$ \\
\hline I4 (Scale 3) & 3.23 & 3.56 & 4.4139 & $\mathrm{p}<.05$ \\
\hline I7 (Scale 4) & 2.82 & 3.69 & 27.5234 & $\mathrm{p}<.000$ \\
\hline I8 (Scale 3) & 3.25 & 3.66 & 6.6696 & $\mathrm{p}<.01$ \\
\hline I9 (Scale 3) & 3.50 & 3.88 & 5.4668 & $\mathrm{p}<.05$ \\
\hline I10 (Scale 3) & 3.79 & 4.18 & 5.8003 & $\mathrm{p}<.05$ \\
\hline I11 (Scale 3) & 3.94 & 4.25 & 4.8865 & $\mathrm{p}<.05$ \\
\hline I17 (Scale 3) & 2.90 & 3.29 & 4.5335 & $\mathrm{p}<.05$ \\
\hline One (Intrinsic motives) & 3.61 & 3.87 & 4.6719 & $\mathrm{p}<.05$ \\
\hline Two (Personal needs) & 2.94 & 3.29 & 8.3697 & $\mathrm{p}<.01$ \\
\hline Three (Inhibitors) & 3.43 & 3.67 & 5.6286 & $\mathrm{p}<.05$ \\
\hline Four (Extrinsic motives) & 2.98 & 3.50 & 19.8973 & $\mathrm{p}<.000$ \\
\hline
\end{tabular}

Overall, the female respondents rated each one of these factors higher. There were very significant differences ( $\mathrm{p}<.000$ level) for "distance education training provided by the institution" (M23), lack of technological background (I7), and "extrinsic motives" (Scale Four). A Chi-square test was used to test the null hypothesis that there was no relationship between gender and the level of faculty participation in distance education. The Chi-square analysis indicated that gender had no significant effect on the level of faculty participation $(\mathrm{p}<.617)$; therefore, the hypothesis was not rejected.

The percentage of males and females participating and not participating in distance education did not deviate significantly from the group percentages (participators $=14.5 \%$, non-participators $=85.5 \%$ ). The percentage of male faculty respondents participating in distance education was $13.7 \%$, while the percentage for those not participating was $86.3 \%$. The percentage for female faculty respondents participating in distance education was $16 \%$, while the percentage for those not participating was $84 \%$. This indicates that, of the faculty who responded to the survey, males and females were participating at the same level when compared to the overall distribution of male and female respondents. There was no relationship found between gender and level of faculty participation in distance education.

Using only the mean scores for faculty, an ANOVA was calculated to test differences in individual factors (motivating $=\mathrm{M}$, inhibiting $=\mathrm{I}$ ) or in the 4 scales by age ranges. Significant differences were found in 3 motivating factors and four inhibiting factors. Results are found in Table 6.

Table 7: ANOVA calculated significant differences found regarding age of respondent and motivating or inhibiting factors

\begin{tabular}{|l|l|l|l|l|r|r|}
\hline Factor & Under 30 years & $\mathbf{3 0 - 4 5}$ years & 45-60 years & $\mathbf{6 0}+$ years & F - score & Significance level \\
\hline M13 (Scale 2) & 3.44 & 2.93 & 2.66 & 2.29 & 3.5613 & $\mathrm{p}<.05$ \\
\hline M20 (Scale 2) & 3.67 & 2.93 & 2.85 & 2.52 & 3.2545 & $\mathrm{p}<.05$ \\
\hline M21 (Scale 2) & 3.44 & 3.03 & 2.58 & 2.64 & 2.7237 & $\mathrm{p}<.05$ \\
\hline I9 (Scale 3) & 4.05 & 3.56 & 3.48 & 4.11 & 2.9705 & $\mathrm{p}<.05$ \\
\hline
\end{tabular}




\begin{tabular}{|l|l|l|l|l|r|r|}
\hline I14 (Scale 3) & 3.95 & 3.56 & 3.33 & 4.07 & 3.5200 & $\mathrm{p}<.05$ \\
\hline I16 (Scale 3) & 3.42 & 3.20 & 2.81 & 3.56 & 3.7392 & $\mathrm{p}<.05$ \\
\hline I17 (Scale 3) & 3.47 & 3.21 & 2.80 & 2.67 & 2.7977 & $\mathrm{p}<.05$ \\
\hline
\end{tabular}

Overall, faculty who are under 30 years of age were more concerned about these factors than older faculty, except for " lack of grants for materials/expenses" (I9), "lack of monetary support for participation" (I14), and "lack of salary increase" (I16) where faculty over 60 years of age were more concerned. The other factors listed refer to "visibility for jobs" (M13), "career exploration" (M20), and "credit or lack of credit toward promotion and tenure" (M21 and 117) for participation in distance education. A Chi-square test was used to test the null hypothesis that there was no relationship between age and the level of faculty participation in distance education. The Chi-square analysis indicated that age had no significant effect on the level of faculty participation $(\mathrm{p}<.674)$; therefore, the hypothesis was not rejected.

The percentage of faculty within each age range, participating and not participating in distance education, did not deviate significantly from the group percentages (participators $=14.1 \%$, non-participators $=$ 85.9\%), except for the under 30 years of age group (5\%). The percentage of faculty respondents within the 30-45-age range participating in distance education was $15.4 \%$, while the percentage for those not participating was $84.6 \%$. The percentage for faculty respondents within the 45-60-age range participating in distance education was $14.4 \%$, while the percentage for those not participating was $85.6 \%$. The percentage for faculty respondents within the 60+-age range was $14.3 \%$, while the percentage for those not participating was $85.7 \%$. This indicates that, in spite of age group, the faculty who responded to the survey were participating at the same level when compared to the overall distribution of respondents' ages. There was no relationship found between age and level of faculty participation in distance education.

Using only the mean scores for faculty, an ANOVA was calculated to see if there were differences in individual factors (motivating $=\mathrm{M}$, inhibiting $=\mathrm{I}$ ) or in the 4 scales by position level. Significant differences were found in nine motivating factors, one inhibiting factors, and two scales. Results are found in Table 7.

Table 8: ANOVA calculated for differences by position level of respondents

\begin{tabular}{|l|l|l|l|l|r|r|}
\hline Factor & Full Prof. & Assoc. Prof. & Asst. Prof. & Instr. & F-score & Significance level \\
\hline M2 (Scale 2) & 2.11 & 2.09 & 3.12 & 2.69 & 8.7972 & $\mathrm{p}<.000$ \\
\hline M3 (Scale 1) & 3.43 & 3.28 & 4.07 & 3.88 & 4.0310 & $\mathrm{p}<.01$ \\
\hline M9 (Scale 2) & 2.60 & 2.75 & 3.35 & 3.69 & 5.6240 & $\mathrm{p}<.001$ \\
\hline M13 (Scale 2) & 2.54 & 2.63 & 3.33 & 3.81 & 7.9051 & $\mathrm{p}<.000$ \\
\hline M16 (Scale 4) & 2.90 & 3.03 & 3.49 & 3.25 & 2.6496 & $\mathrm{p}<.05$ \\
\hline M20 (Scale 2) & 2.63 & 2.80 & 3.53 & 3.50 & 6.8391 & $\mathrm{p}<.001$ \\
\hline M21 (Scale 2) & 2.24 & 2.91 & 3.88 & 3.69 & 19.5159 & $\mathrm{p}<.000$ \\
\hline M22 (Scale 2) & 2.96 & 3.35 & 3.75 & 3.69 & 3.7749 & $\mathrm{p}<.05$ \\
\hline M29 (Scale 4) & 2.95 & 3.15 & 3.60 & 3.19 & 2.6533 & $\mathrm{p}<.05$ \\
\hline I17 (Scale 2) & 2.66 & 2.91 & 3.83 & 3.75 & 10.6893 & $\mathrm{p}<.000$ \\
\hline Two (Personal needs) & 2.83 & 2.99 & 3.55 & 3.57 & 9.3004 & $\mathrm{p}<.000$ \\
\hline $\begin{array}{l}\text { Four (Extrinsic } \\
\text { motives) }\end{array}$ & 3.02 & 3.15 & 3.46 & 3.41 & 2.9120 & $\mathrm{p}<.05$ \\
\hline
\end{tabular}

Overall, faculty who were Assistant Professors or Instructors were more likely to be either motivated or inhibited by these factors, with very significant differences $(\mathrm{p}<.001$ level) for "job security" (M9) and "career exploration" (M20), and highly significant differences ( $<$ <.000 level) for "graduate training 
received" (M2), "visibility for jobs" (M13), "credit or lack of credit toward promotion and tenure" (M21 and I17), and "personal needs" (Scale 2). A Chi-square test was used to test the null hypothesis that there was no relationship between faculty position and the level of faculty participation in distance education. The Chi-square analysis indicated that faculty position had no significant effect on the level of faculty participation $(\mathrm{p}<.395)$; therefore, the hypothesis was not rejected.

The percentage of faculty within faculty position level participating and not participating in distance education did not deviate significantly from the group percentages (participators $=14.4 \%$, nonparticipators $=85.6 \%$ ), except for Instructors where only 1 out of 16 participated in distance education. The percentage of faculty respondents who were full professors participating in distance education was $11.9 \%$, while the percentage for those not participating was $88.1 \%$. The percentage for faculty respondents who were associate professors participating in distance education was $18.9 \%$, while the percentage for those not participating was $81.1 \%$. The percentage for faculty respondents who were assistant professors participating in distance education was $17.0 \%$, while the percentage for those not participating was $83.0 \%$. This indicates that, in spite of faculty position level, the faculty who responded to the survey were participating at the same level when compared to the overall distribution of position levels. There was no relationship found between faculty position level and level of faculty participation in distance education.

Using only the mean scores for faculty, an ANOVA was calculated to see if there were differences in individual factors (motivating $=\mathrm{M}$, inhibiting $=\mathrm{I}$ ) or in the 4 scales by tenure status. Significant differences were found in ten motivating factors, two inhibiting factors, and one scale. Results are found in Table 8.

Table 9: ANOVA calculated for differences by tenure status of respondents

\begin{tabular}{|l|l|l|r|r|}
\hline Factor & Tenured & Non-tenured & F - score & Significance level \\
\hline M2 (Scale 2) & 2.04 & 2.94 & 28.1901 & $\mathrm{p}<.000$ \\
\hline M3 (Scale 1) & 3.32 & 4.01 & 14.2171 & $\mathrm{p}<.000$ \\
\hline M9 (Scale 2) & 2.62 & 3.39 & 16.2421 & $\mathrm{p}<.001$ \\
\hline M11 (Scale 4) & 2.89 & 3.24 & 4.2128 & $\mathrm{p}<.05$ \\
\hline M13 (Scale 2) & 2.49 & 3.48 & 31.2491 & $\mathrm{p}<.000$ \\
\hline M14 (Scale 2) & 2.84 & 3.25 & 4.8255 & $\mathrm{p}<.05$ \\
\hline M20 (Scale 2) & 2.68 & 3.40 & 15.9971 & $\mathrm{p}<.000$ \\
\hline M21 (Scale 2) & 2.45 & 3.74 & 46.9029 & $\mathrm{p}<.000$ \\
\hline M22 (Scale 2) & 3.13 & 3.58 & 4.6383 & $\mathrm{p}<.05$ \\
\hline M29 (Scale 4) & 3.03 & 3.41 & 4.2125 & $\mathrm{p}<.05$ \\
\hline I17 (Scale 2) & 2.68 & 3.79 & 38.5038 & $\mathrm{p}<.000$ \\
\hline Two (Personal needs) & 2.87 & 3.47 & 23.9709 & $\mathrm{p}<.000$ \\
\hline
\end{tabular}

Overall, the non-tenured faculty rated these issues higher than tenured faculty. There were highly significant differences (.001 or .000 levels) between tenured and non-tenured faculty on "graduate training received" (M2), "opportunity for scholarly pursuit" (M3), "job security" (M9), "visibility of jobs" (M13), "career exploration" (M20), "credit or lack of credit toward tenure and promotion" (M21 and I17), and the "personal needs" scale (Scale Two). A Chi-square test was used to test the null hypothesis that there was no relationship between tenure status and the level of faculty participation in distance education. The Chisquare analysis indicated that tenure status had no significant effect on the level of faculty participation (p $<$.854); therefore, the hypothesis was not rejected.

The percentage of tenured and non-tenured participating and not participating in distance education did not deviate significantly from the group percentages (participators $=14.2 \%$, non-participators $=85.8 \%$ ). The 
percentage of tenured faculty respondents participating in distance education was $14.0 \%$, while the percentage for those not participating was $86.0 \%$. The percentage for non-tenured faculty respondents participating in distance education was $14.9 \%$, while the percentage for those not participating was $85.1 \%$. This indicates that, of the faculty who responded to the survey, tenured and non-tenured faculty were participating at the same level when compared to the overall distribution of respondents. There was no relationship found between tenure status and level of faculty participation in distance education

\section{Discussion}

While there no statistically significant differences were found for faculty gender, age range, rank or tenure status in DE participation, differences were found between faculty and administrators perceptions of what motivates faculty DE participation. Faculty participants in distance education appear to be more highly motivated by intrinsic issues of Scale 1 (e.g., intellectual challenge, and overall job satisfaction) than nonparticipating faculty. Along those same lines, non-participating faculty seem to be more effected by personal needs of Scale 2 (e.g., release time, credit toward promotion and tenure, and merit pay), inhibitors of Scale 3 (e.g., lack of release time, lack of merit pay, lack of monetary support for participation), and extrinsic motives of Scale 4 (e.g., expectation by university, requirement by department, lack of technical background).

This finding may be due to the fact that faculty participating in distance education have already responded to personal needs and external pressures, feel comfortable with their technical skills and are ready to move forward in developing programs and supporting students through distance education. They know what works for them and what does not, while non-participating faculty may be caught up in the personal technical concerns, preventing them from concentrating on pedagogical issues.

Administrators rated factors associated with personal needs of Scale 2 higher than either DE participating or non-participating faculty. Clearly, the administrators who responded to this survey considered issues of financial support and release time/reduced teaching load to be very important to faculty when deciding whether to participate in distance education or not. This finding could be due to prior experience, but this cannot be indicated from this study. Overall, the administrators in this study did not appear to truly understand what would motivate faculty who do participate in distance education, but had a clear perception of what would inhibit faculty from DE participation. Also of interest is the fact that the nonparticipating faculty rated personal needs Scale 2 highly. This finding, combined with administrators rating this scale highly, may give some administrators support for continuing to offer financial incentives and compensation for teaching distance education courses.

The female responses in this study were significantly different from the males, specifically on issues related to extrinsic motives. Lack of technological background supports other research that has demonstrated women are not attracted to using technology. As for overall extrinsic motives, these are factors having to do with administrative support and encouragement for participation. The results of this study do not answer why female respondents appear to be more willing to be motivated by what is expected, required and/or supported through administrative channels, which would need to be a separate study.

Age, faculty level, and tenure status demonstrated significant differences in areas relating to personal needs. Most specifically, differences were found for faculty under age 30, at the Assistant Professor or Instructor level, and non-tenured. This, too, is not surprising since these three faculty groups are closely related and have the most to gain or lose from participating in distance education, including the possibility of a negative effect on promotion and tenure or a positive impact on career exploration and job opportunities. In research extensive universities, these groups are pressured to conduct research and publish results. Preparing for and teaching a distance education course is reported as very time consuming if done alone, taking away from precious research time. Therefore, younger and junior faculty, who may be more adept at using technology and excited about new opportunities, may be dissuaded from 
participating due to competing needs.

\section{Conclusion}

As noted previously, faculty are the key to a successful distance education program. This study showed that faculty participating in distance education were much more likely to be motivated to participate by issues that are intrinsic motivations (i.e., overall job satisfaction), rather than personal needs (i.e., release time), negative issues (i.e., lack of support from administrators), or extrinsic motives (i.e., lack of technical background). This finding supported, and expanded, work by Rockwell, Schauer, Fritz and Marx (1999), who reported that distance education faculty state intrinsic incentives for participating in distance education. In addition, non-participating faculty in this study noted personal needs and extrinsic motives as more motivating for participation than intrinsic motivations. And lastly, the administrators in this study did not seem to understand what motivates faculty to participate in distance education, but were very sure what would inhibit participation.

The concerns of junior, untenured faculty need careful consideration. This group of faculty may be more likely to be comfortable using technology and, therefore, more apt to be intrigued by teaching a distance course; but they are also more likely to need to use time in the pursuit of tenure, especially in a research extensive university. Further research is needed to determine whether teaching in distance education programs negatively effects junior, untenured faculty, and if so, how.

Administrators must understand what motivates and inhibits faculty distance education participation in order to maximize efforts, yet this study suggests that administrators may not understand what motivates faculty to participate. This lack of understanding of motivating factors may negatively effect distance education program development. It may skew compensation and incentive efforts toward the extrinsic scale (i.e., expectation by university) rather than concentrating on what really motivates faculty (i.e., overall job satisfaction) or moving past issues of how to use technology (i.e., learning software) toward developing pedagogical models for distance education.

Faculty and administrators must work together to make a distance program successful. Understanding each other's perspectives will make the difference between a successful program and one that is either marginal or weak. It is easy to concentrate on technical training and financial rewards, which cater to the extrinsic and personal scales, and ignore the intrinsic scale that appears to motivate faculty to explore new ways of teaching and learning. Using the factors of the motivating scale and moving discussions toward pedagogical concepts will bring faculty toward teaching in distance education programs. This study needs to be expanded to include additional university and college faculty, including those from 2-year and 4year institutions, liberal arts colleges and research extensive universities, to determine whether these findings are unique to this institution. This extensive study might begin to ascertain whether individual institution culture makes the difference in student and administrator responses.

\section{References}

Beaudoin, M.R. (1990). The instructor's changing role in distance education. The American Journal of Distance Education 4 (2): 21-29.

Beaudoin, M.R. (1998). A new professoriate for the new millennium. DEOSNEWS 8 (5), Article 98-00004. Retrieved August 30, 1998 from http://www.outreach.psu.edu/ASCDE/DEOS.html

Berge, Z.L. (1998). Changing roles of teachers and learners are transforming the online classroom. Online- 
Ed August 30, 1998, Article 74. Retrieved August 30, 1998 from http://www.edfac.unimelb.edu.au/onlineed

Betts, K.S. (1998). Factors influencing faculty participation in distance education in postsecondary education in the United States: An institutional study. (Doctoral dissertation, The George Washington University.) Dissertation Abstracts International: UMI No. 9900013.

Betts, K.S. (1998). Personal communication, November, 20, 1998.

Bower, B.L. (2001). Distance Education: Facing the faculty challenge. Online Journal of Distance Learning Administration, 4(11): Summer. Retrieved March 22, 2002 from http://www.westga.edu/ distance/ojdla/summer42/bower42.html.

Carnevale, D. (2001). Union offers warning on distance education. The Chronicle of Higher Education, 48(3): A39.

Clark, T. (1993). Attitudes of higher education faculty toward distance education: A national survey. The American Journal of Distance Education 7 (2): 19-33.

Dillon, C. \& Walsh, S.M. (1992). Faculty: The neglected resource in distance education. The American Journal of Distance Education 6 (3): 5-21.

Higher Education Research Institute. (1999). Faculty survey. Accessed March 22, 2002 from http://www.gseis.ucla.edu/heri/press faculty.htm.

Koontz, F.R. (1989). Critical barriers to the adoption of instructional television in higher education. Educational Technology 29 (4): 45-48.

McKenzie, B.K. (2000). Needs, concerns and practices of online instructors. Online Journal of Distance Learning Administration, 3(3): Fall. Retrieved March 22, 2002 from http://www.westga.edu/ distance/ojdla/fall33/mckenzie33.html.

Olcott, D.J. (1991). Bridging the gap: Distance learning and academic policy. Continuing Higher Education Review 55 (1 and 2): 49-60.

Olcott, D.J. (1992). Policy issues in statewide delivery of university programs by telecommunications. The American Journal of distance Education 6 (1): 14-26.

Olcott, D.J. (1993). Access to learning: Integrating telecommunications instruction in university extended degree programs. The Journal of Continuing Higher Education 41 (1): 16-24.

Olcott, D. \& Wright, S.J. (1995). An institutional support framework for increasing faculty participation in postsecondary distance education. The American Journal of Distance Education 9 (3): 5-17.

Paulson, K. (2002). Reconfiguring faculty roles for virtual settings. The Journal of Higher Education, 73(1): 123-140.

Rockwell, K., Schauer, J., Fritz, S.M., \& Marx, D.B. (1999). Incentives and obstacles influencing higher education faculty and administrators to teach via distance. Online Journal of Distance Learning Administration, 2(3): Winter. Retrieved March 22, 2002 from http://www.westga.edu/ distance/ojdla/winter24/rockwell24.html.

Seay, R, Rudolph, H.R., \& Chamberlain, D.H. (2001). Faculty perceptions of interactive television instruction. Journal of Education for Business, 77 (2): 99-105. 
Strain, J. (1987). The role of the faculty member in distance education. The American Journal of Distance Education 1 (2): 61-65.

Taylor, J.C. \& White, J.V. (1991). Faculty attitudes towards teaching in the distance education mode: An exploratory investigation. Research in Distance Education July: 7-11.

U.S. Department of Education. (1999) Distance education at postsecondary education institutions: 199798. (NCES Publication No. 2000-013). Washington, D.C.: Lewis, L., Snow, K., Farris, E., Levin, D., \& Greene, B.

Wagner, E.D. \& Elms, R.R. (1993). Faculty incentives for distance education. Paper presented at the "Distance Education: Sharing the Experience” Conference, Portland, OR, Oregon State University, October.

Wolcott, L.L. (1993). Faculty planning for distance teaching. The American Journal of Distance Education 7 (1): 26-36.

Online Journal of Distance Learning Administration, Volume V, Number I, Spring 2002

State University of West Georgia, Distance Education Center

Back to Journal of Distance Learning Administration Contents 